\title{
Analysis of public debt in the European Union - issues related to its sustainability ${ }^{*}$
}

\author{
Mihaiu Diana Marieta \\ University of Sibiu \\ Romania \\ cindea_diana@yahoo.com
}

\begin{abstract}
The purpose of this paper is to analyze the public debt in the EU member coun-
Received:

May, 2014

tries based on the "golden rule" of state indebtedness. This study analyzes the type of relationships that exist in the European Union (EU27) in the period 2008-2012, between the level of the public debt and: public investments, unemployment rate and economic growth in order to identify the destinations and effects of the public debt that represent pillars in the analysis of its sustainability. The analysis revealed an inverse relationship between public debt and public investments, thus increasing the public debt is not listed in stimulating public investments, but on the contrary it can

1st Revision:

June, 2014

Accepted:

September, 2014

DOI:

$10.14254 / 2071-$ $8330.2014 / 7-2 / 2$
\end{abstract} be noticed their decline.

Keywords: public debt, public investment, unemployment, GDP growth.

JEL classification: H63.

\section{INTRODUCTION}

The situation of public loans and by default of public debt is a real current issue with which many developed and developing economies of the world are facing. The figures regarding the public debt share in GDP are intensely publicized and thus the states are incriminated or "applauded" in terms of governance quality. Of course that the absolute level of the public debt and its share in GDP are important indicators that deserve a careful monitoring, but the analysis must be thorough. The level of the public debt should be seen in comparison with the effects produced by these borrowed money, the effectiveness of using these funds and not least, the evolution and sustainability of the public debt should be determined. The states that register rates above average over the permissible level of public but that have redirected their funds into investment projects that will generate jobs cannot be blamed, these will generate an economic environment attractive to investors, who will contribute to the long-term growth of wealth of the population and will generate a real economic growth. Also, we cannot take as example the states that register low levels of public debt but which have used these borrowed financial resources to finance some unproductive expenses, which do not produce any economic value.

This work was supported by the strategic grant POSDRU/159/1.5/S/133255, Project ID 133255 (2014), co-financed by the European Social Fund within the Sectorial Operational Program Human Resources Development 2007-2013. 


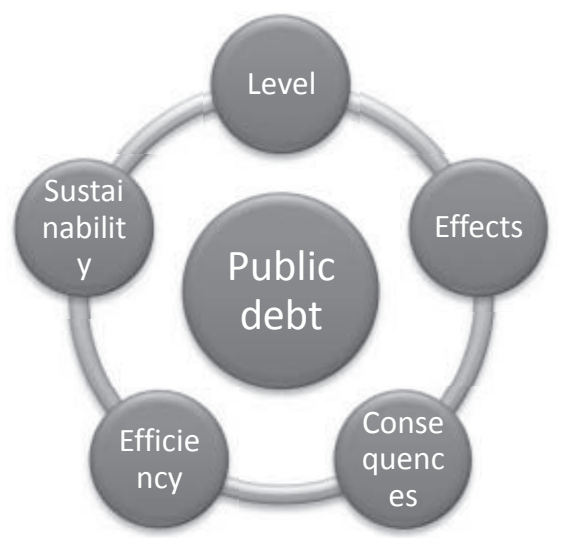

Figure 1: Analysis directions of the public debt Source: authors' own development

The purpose of this paper is to analyze the public debt in the EU member countries based on the "golden rule" of state indebtedness. To ensure a national debt sustainability premise it is indicated that the state loans to be directed towards public investments. Thus, increasing public investments will create new jobs in the economy leading to a lower unemployment and together will help to increase the government and households consumption. This route of sovereign indebtedness will be able to ensure a healthy economical growth. We will test in this article how to respect the "golden rule" and this route at the European Union level since the onset of the global crisis.

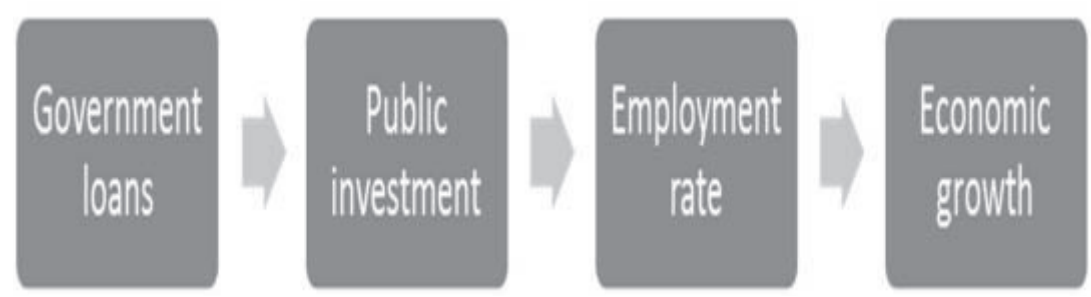

Figure 2: The government loans circuit

Source: author's own computations

We will try to answer in this article to the following questions related to the issue of public debt in EU countries:

- The increase of the public debt generates an increase in the public investments; mainly reducing the public debt is made based on affecting the public investments?

- The increase of the public debt stimulates the creation of new work places or on the contrary has a negative effect over the unemployment rate?

- What type of link exists between public debt and economic growth: direct, inverse, nonlinear? 


\section{LITERATURE REVIEW}

The debates over the state loans and public debt are generally focused on identifying the answers to the above questions. State loans are public resources with tremendous character, to which the state appeals for balancing the budget. Lately, with the onset of the financial crisis, the European countries and others have used extensively this funding source generating a new problem, namely a sovereign debt crisis. And Bunescu L. highlighted the consequences of an excessive indebtedness and irrational of the state: “(...) on long term the loans generate an increase in fiscal pressure, influencing the behavior of financial market investors, that lead to changes in interest rates" (Bunescu L., 2011, page 39). At present, the attention of the public decision makers from the EU member countries, but also from the United States of America and Japan is moving towards ways to reduce government debt: by controlling and reducing the public expenditure, by increasing the tax rate or by a combination of these two measures, as chosen by the United States of America.

Opinions in the direction of the public debt - public investments relationship are often contrary. Some studies have demonstrated that the obligation to limit the public debt to a certain level has the effect of reducing the public spending for investments (Balassone F., Franco D., 2000). On the other hand, A. Greiner, $B$. Fincke have demonstrated that a high level of public debt will generate an increase in demand for public resources necessary for financing the debt service that will generate a decline of the public investments (Greiner A., Fincke B ., 2009). Manmohan S. Kumar and Woo Jaejoon established that there is an inverse relationship between the high levels of the public debt (over 90\% of GDP) and the public investments determining that on average there is an increase of 10 percentage points of the initial public debt associated with a decrease of the investments of 0.4 percentage points of GDP, the impact being greater in the emerging economies (Kumar M.S, Jaejoon Woo, 2010, page 21).

A state's budget deficit can be covered either through tax measures, but that mainly have as immediate effect affecting the consumption and slowing the economic growth, either by contracting state loans and putting pressure on future generations. From this last option results the need to ensure a public debt sustainability. As it is sustained by Humberto Nuno Rito Ribeiro, Tadas Vaicekauskas si Auśrine Lakštutiene "a debt is sustainable if it is used to generate economic growth and benefits higher than initial costs, otherwise serious public finance issues are about to appear. (...) government has to maintain the equilibrium between taxation and debt financing in order to maintain economic and financial stability in a long run" (Ribeiro H.N.R., Vaicekauskas T., Lakštutiene A., 2012, page 915). The public debt sustainability is researched in a study of the authors Edward E Buffe, Andrew Berg, Catherine Pattillo, R. afael Portillo, and Luis Felipe Zanna in which they criticize the methodology of the World Bank and of the International Monetary Fund of analyzing the sustainability of the public debt because it doesn't give the proper importance to the public investments economic growth relationship in the methodology used and the above mentioned authors develop their own model based on this relationship (Buffie E.E, Berg A., Pattillo C., Portillo R., Zanna L.F, 2012). Although the public debt sustainability is a very important aspect of the public finances, there are no universally recognized indicators that could allow its testing. Lucian Albu has designed a function of the public debt sustainability that must strive for zero dynamics, as a condition of the sustainability. The optimal level of these public debt sustainability function is achieved if there is an economic growth of 3.6\% (Albu L., 2008, page 3 and 6).

The relationship public debt - economic growth is intensely analyzed from several perspectives: if the increase of the state indebtedness always generates an economic growth and if that growth is sustainable, if reducing the public debt determines, in the short term, an economic slowdown. Antonio Afonso and J.G Alegre analyzed how the budget components, meaning the categories of expenditure and income, influence the economic growth in the EU 15, during the period 1971-2006. The result of the study shows that the 
public investments have a positive impact on the economic growth, which is a statistically significant result (Antonio A., Gonzales A.J., 2011, page 720).

C. Checherita and P. Rother, analyzing the relationship between public debt and economic growth in the Euro Zone has demonstrated the existence of a non-linear, concave relationship, which has the turning point of $90 \%-100 \%$ of the GDP debt. This means that the high levels (over 90\% of GDP) and rising of the public debt are harming the economic growth through the light of the growth of the long term interest rate that affects the private investments. (Checherita C., Rother P., 2010, page 22). To a similar conclusion ended up also Manmohan S. Kumar and Jaejoon Woo: "on average, a 10 percentage point increase in the initial debt-to-GDP ratio is associated with a slowdown in annual real per capita GDP growth of around 0.2 percentage points per year, with the impact being smaller (around 0.15) in advanced economies. There is some evidence of nonlinearity, with only high (above 90 percent of GDP) levels of debt having a significant negative effect on growth" (Kumar M.S and Jaejoon Woo, 2010, page 21).

If the governments of the EU member countries keep an eye on the public debt and aim at its reduction, the U.S. government is more lenient when it comes to this problem and aims to increase the public debt limit with the condition that the public spending control is ensured. Josh Bivens sustains the idea of indebtedness growth only if it contributes to lowering unemployment by creating jobs through public investments and private sector incentives (Bivens J, 2012).

A number of economic studies analyze the influence of the public debt over the employment of labor and over the economic growth. A study conducted by Mario Coccia in the 27 EU member states for the period 1995-2009 demonstrates the existence of a negative impact of the public debt over the employment rate workforce, lowering the unemployment rate can be achieved by "increasing research and development ( $R$ $\& D)$ intensity and spending in human resource ", but these programs are affected by the austerity measures taken by governments in order to reduce the national budget deficits and the level of the public debt (Coccia M., 2013, page 327).

Study regarding the relationship between public debt and public investment, unemployment rate, economic growth in EU 27 during 2008 - 2012

This study analyzes the type of relationships that exist in the European Union (EU27) in the period 2008 -2012, between the level of the public debt and: public investments, unemployment rate and economic growth in order to identify the destinations and effects of the public debt that represent pillars in the analysis of its sustainability. In this regard, using statistical analysis software SPSS, it was performed an analysis of the correlations that exist between the public debt and public investments, unemployment, economic growth through the Pearson correlation coefficient.

Also, we will achieve a positioning of the level of the indicators mentioned above in Romania compared to the EU average. 
Table 1

The analysis of the correlation between the general government gross debt and the general government fixed investment, unemployment rate, real GDP growth rate

\begin{tabular}{|c|c|c|c|c|}
\hline & & $\begin{array}{l}\text { General govern- } \\
\text { ment fixed invest- }\end{array}$ & Unemployment rate & Real GDP growth \\
\hline General government & Pearson Correlation &,$- 572 * *$ & ,233 &,- 187 \\
\hline & Sig. (2-tailed) &, 002 & ,242 & ,350 \\
\hline & $\mathrm{N}$ & 27 & 27 & 27 \\
\hline & & $\begin{array}{l}\text { General govern- } \\
\text { ment fixed invest- } \\
\text { ment } \% \text { GDP }\end{array}$ & Unemployment rate & $\begin{array}{l}\text { Real GDP growth } \\
\text { rate }\end{array}$ \\
\hline General government & Pearson Correlation &,$- 563 * *$ &,- 084 & ,429* \\
\hline gross debt & Sig. (2-tailed) & ,002 & ,677 & ,026 \\
\hline & $\mathrm{N}$ & 27 & 27 & 27 \\
\hline & & $\begin{array}{l}\text { General govern- } \\
\text { ment fixed invest- } \\
\text { ment } \% \text { GDP }\end{array}$ & Unemployment rate & $\begin{array}{l}\text { Real GDP growth } \\
\text { rate }\end{array}$ \\
\hline General government & Pearson Correlation &,$- 545^{* *}$ &,- 055 &,$- 389 *$ \\
\hline gross debt & Sig. (2-tailed) & ,003 & ,784 & ,045 \\
\hline & $\mathrm{N}$ & 27 & 27 & 27 \\
\hline & & $\begin{array}{l}\text { General govern- } \\
\text { ment fixed invest- } \\
\text { ment \%GDP }\end{array}$ & Unemployment rate & $\begin{array}{l}\text { Real GDP growth } \\
\text { rate }\end{array}$ \\
\hline General government & Pearson Correlation &,$- 595 * *$ & ,208 &,$- 743 * *$ \\
\hline gross debt & Sig. (2-tailed) &, 001 & ,299 & ,000 \\
\hline & $\mathrm{N}$ & 27 & 27 & 27 \\
\hline & & $\begin{array}{l}\text { General govern- } \\
\text { ment fixed invest- } \\
\text { ment } \% \text { GDP }\end{array}$ & Unemployment rate & $\begin{array}{l}\text { Real GDP growth } \\
\text { rate }\end{array}$ \\
\hline General government & Pearson Correlation &,$- 699 * *$ &, $431 *$ &,$- 677 * *$ \\
\hline gross debt & Sig. (2-tailed) &, 000 & 025 &, 000 \\
\hline & $\mathrm{N}$ & 27 & 27 & 27 \\
\hline
\end{tabular}

** Correlation is significant at the 0.01 level (2-tailed).

* Correlation is significant at the 0.05 level (2-tailed).

Source: author's own computations.

Analyzing the correlation between the public debt level and the level of the public investments in the EU 27, we can notice an inverse relationship (relationship demonstrated by obtaining an average Pearson correlation coefficient of -0.57 for the period 2008-2012), which means that the public investments register a decrease with the increase of the public debt and not an increase such as it would have been desirable in order to ensure the sustainability of the public debt. As the public debt increases a decrease in the public investments is accentuated due to the pressure of the public debt burden over the state budget verifying in this case the theory of A. Greiner, B. Fincke presented in Part 1 of the paper.

Testing the correlation between public debt and the unemployment level, during 2008-2012, has resulted in a lack of significant correlation, demonstrated by the value of average Pearson correlation coef- 
ficient of +0.14 . There is however a weak direct relationship in the analyzed period, meaning the rising of the public debt generates the rising of unemployment rate, but the correlation coefficient has a low value (between 0.2 and 0.4). In 2009 and 2010 it can be noticed a negative Pearson coefficient, but of very small value, insignificant one $(-0.084$ and -0.055$)$ because in these years unemployment also grew due to the effects of world financial crises. This correlation, although unfavorable to the national economies, makes sense if you also consider the previous result according to which the increase of the governmental debt generates the lowering of the public investments. The downward trend of the investments also threatens the number of jobs from the economy.

In the analyzed period, 2008-2012, in the EU 27, between public debt and economic growth there is an inverse, negative relationship, from the moment when the public debt exceeds $60 \%$ of GDP, which means that the growth of the public debt causes a slowdown of the economic growth. Up to the level of $60 \%$ there is a linear relationship (see Table 1 and 2).

In order to test the sustainability of public debt, International Monetary Fund (IMF) has conducted a study on the developed and emerging economies setting that the maximum level of the public debt sustainability is between $183-192 \%$ of GDP in developed countries and between 60-80\% of GDP in emerging economies (International Monetary Fund, 2011, pg.14). The only developed economy that exceeded this threshold of sustainability is Japan. In the case of the emerging economies in the EU, the only countries that record a level of the public debt in the range of $60-80 \%$ of GDP are: Hungary, Cyprus.

Table 2

The average value of the public debt, public investment, unemployment and economic growth rates in the EU-27 in 2008-2012

\begin{tabular}{|c|c|c|c|c|}
\hline Year & $\begin{array}{c}\text { General government } \\
\text { gross debt \% GDP }\end{array}$ & $\begin{array}{c}\text { General government } \\
\text { fixed investment } \\
\text { \%GDP }\end{array}$ & Unemployment rate & Real GDP growth rate \\
\hline 2008 & 47 & 3.48 & 6.28 & 1.27 \\
\hline 2009 & 56 & 3.5 & 8.93 & -5.62 \\
\hline 2010 & 61 & 3.33 & 10.12 & 1.71 \\
\hline 2011 & 65 & 3.04 & 9.94 & 1.89 \\
\hline 2012 & 69 & 2.87 & 10.62 & -0.09 \\
\hline
\end{tabular}

Source: author's own computation based on EUROSTAT statistics

Even if the level of the public debt is not a problem in all the EU countries (in 2012, the public debt as\% of GDP ranged from $9.8 \%$ in Estonia to $156 \%$ in Greece) using state loans, their destinations does not produce real benefits for the economies that would cover the public debt burden. In most EU member states the public investments have declined, the unemployment rate has increased due to the increased indebtedness of the state. This situation shows that the state loans were used to cover some unproductive expenditures affecting the sustainability of the public debt.

Romania does not make an exception from this unfavorable situation, even if it records a lower level of the public debt compared to the EU average (see Table 3). The low level of the public debt as \% of GDP does not illustrate a stable situation of the country and does not ensure the sustainability of the public debt if we were to consider Romania's high lack of ability to generate primary budgetary surpluses to reduce the burden of paying a high public debt service. 
Table 3

The value of the public debt, public investments, unemployment rate and economic growth rate in Romania in the period 2008-2012

\begin{tabular}{|c|c|c|c|c|}
\hline Year & $\begin{array}{c}\text { General government } \\
\text { gross debt \% GDP }\end{array}$ & $\begin{array}{c}\text { General government } \\
\text { fixed investment } \\
\text { \%GDP }\end{array}$ & Unemployment rate & $\begin{array}{c}\text { Real GDP growth } \\
\text { rate }\end{array}$ \\
\hline 2008 & 13.4 & 6.6 & 5.8 & 7.3 \\
\hline 2009 & 23.6 & 5.9 & 6.9 & -6.6 \\
\hline 2010 & 30.5 & 5.7 & 7.3 & -1.1 \\
\hline 2011 & 33.4 & 5.2 & 7.4 & 2.2 \\
\hline 2012 & 37.9 & 4.7 & 7 & 0.7 \\
\hline
\end{tabular}

Source: author's own computation based on EUROSTAT statistics

Analyzing the situation in Romania, is can be seen in 2012 an increase of the public debt expressed as a percentage of GDP of $282 \%$ compared to the year 2008. Meanwhile, the public investments expressed as $\%$ of GDP have dropped by about $30 \%$, while the unemployment rate increased by $20 \%$. The relationship between the public debt and economic growth is a nonlinear one. It can be inferred from this an unproductive use of the government loans that will affect their ability for repayment. Romania has kept under control the budgetary deficit at the expense of the public investments, the economic growth was achieved due to increased exports, industry and agriculture.

Making a comparative analysis of the indicators mentioned above in Romania and the EU-27 average in the period 2008 -2012 we can extract the following remarks:

- The public debt in Romania, although lower as a share of GDP compared to the EU average, recorded a growth rate between $2008-2012$ by $282 \%$ compared to $146 \%$ of the EU27 average, so almost double;

- Public investments in Romania (expressed as \% of GDP) fell by 30\%, the EU average decrease was of $18 \%$;

- Unemployment in Romania increased only by 30\%, while the EU average recorded an increase of 70\%;

- The economic growth in Romania exceeds the EU average.

\section{CONCLUSIONS}

The accelerate growth of the public debt in most EU member countries and beyond, with the onset of the economic crisis, has raised the question of its sustainability. Setting the sustainability limit is however difficult to achieve: $60 \%$ of GDP can be a sustainable level for some economies, while for others may be too much, depending on the use of the funds borrowed and on the value created by them to the economy, on the debt structure, on its maturity and afferent cost. As the IMF study shown, the maximum level of the public debt sustainability is between $183-192 \%$ of GDP in developed countries and between $60-80 \%$ of GDP in emerging economies.

Returning to the introductory topics of this article, we can conclude that:

- there is an inverse relationship between public debt and public investments in European Union member states (excluding Croatia) during 2008-2012; thus increasing the public debt is not listed in stimulating public investments, but on the contrary it can be noticed their decline. 
- there is no significant correlation between public debt and unemployment; it was found that there is a direct correlation between public debt and the unemployment rate but of low intensity.

- once the public debt exceeds the level of $60 \%$ of GDP there is a reverse connection between this indicator and the economic growth; up to that level (of $60 \%$ of GDP) it cannot be defined a specific type of significant relationship.

This study was conducted per EU as a whole, but further research direction is to analyze each member country or groups of countries (divided according to the level of economic development), because deviations from the EU average are high.

\section{REFERENCES}

Afonso A, Gonzales A. J., (2011), Economic Growth And Budgetary Components: A Panel Assessment For The EU, Empir Econ 41:703-723, DOI 10.1007/s00181-010-0400-9, Springer-Verlag.

Albu L., (2008), A simulation model of public debt sustainability, MPRAPaper 11713, University Library of Munich, Germany.

Balassone F., Franco D., (2000), Public Investment, The Stability Pact And The 'Golden Rule', Fiscal Studies; vol. 21, no. 2; ProQuest Central, pg. 207-229.

Bivens J., (2012), It's OK To Add To Debt To Grow Jobs, CNN available online at http://edition.cnn.com/2012/06/12/ opinion/bivens-debt-economy. Josh Bivens, an economist, is the research and policy director at the Economic Policy Institute.

Buffie E. E., Berg A., Pattillo C., Portillo R., Zanna L.F., (2012), Public Investment, Growth, and Debt Sustainability: Putting Together the Pieces, IMF Working Paper WP 12/144.

Bunescu L., (2011), International Financing Alternatives For Romanian Central Government, Studies in Business and Economics, vol. 6(3), pages 39.

Checherita C., Rother P., (2010), The Impact Of High And Growing Government Debt On Economic Growth An Empirical Investigation For The Euro Area, European Central Bank Working Paper Series NO 1237 / AUG UST 2010, page 22 .

Coccia M., (2013), Innovation, Employment And Public Debt Across European Countries, African Journal of Business Management Vol. 7(5), pp. 318-330, available online at http://www.academicjournals.org/AJBM, DOI: 10.5897/ AJBM12.627, Academic Journals, page.327

Greiner A., Fincke B., (2009), Public debt and economic growth, Series: Dynamic Modeling and Econometrics in Economics and Finance, Vol. 11, Springer - Verlag.

International Monetary Fund, (2011), Modernizing the Framework for Fiscal Policy and Public Debt Sustainability Analysis, prepared by the Fiscal Affairs Department and the Strategy, Policy, and Review Department, approved by Carlo Cottarelli and Reza Moghadam, page 14.

Kumar M. S., Jaejoon Woo, (2010), Public Debt and Growth, IMF Working Paper, Fiscal Affairs Department, WP/10/174, page 21.

Ribeiro H.N.R., Vaicekauskas T., Lakštutiene A., (2012), The Effect Of Public Debt And Other Determinants On The Economic Growth Of Selected European Countries, Economics And Management, vol. 17 (3), page 915. 